\title{
JOURNAL.RU
}

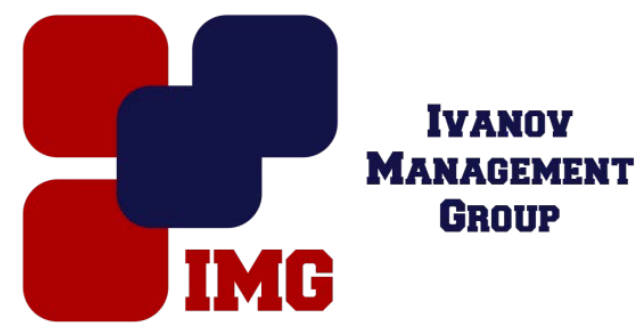

Tyshchenko D.A. Tyumen State University

Tyumen, Russia

doi: 10.18411/lj-31-03-2017-1-05

idsp 000001:lj-31-03-2017-1-05

\section{Social stratification and problem of social inequality}

\begin{abstract}
The article is devoted to the peculiarities of social inequality in the world. Considered slavery as the first historical type of stratification. Particular attention is drawn to the social inequality in antiquity. The characteristic forms of social inequalities associated with social communities.

Keywords: social inequality, class structure of society, stratification, classes, status groups

The problem of inequality, justice relationship developing between people has always been relevant for the study of its scientists.

During the entire course of civilization existence of social inequality remain inevitable. Inequality has always condemned the people subjected to strong criticism, did not cause affectional relationships among members of society, but in the course of the historical development of people with the same tenacity opposed the creation of the "ideal" societies, which are based on the idea of social equality and the lack of inhibition of some members of society by others.

The Company's high level of development characterized by the fact that in them there is an unequal distribution of all kinds of wealth, opportunities, rewards, both between the various groups existing within society and between individuals.

The structure of any society has a lot of parameters, such as age, demographic, ethnic, social class, and so on. The structuring of society creates the preconditions for the emergence of social inequality as each man belongs to various professional, social, age and so on. The presence of differences in the genetic or physical capabilities can also be the basis for the emergence of unequal relations. However, it should be emphasized that social inequality in society is generated primarily by objective factors [3, p. 102]. For any society characterized by social inequality.

Inequality can be characterize as an indicator by which it can be stated that certain groups in society are located above or below with respect to other groups. In the social
\end{abstract}


sciences the most well-known term characterizing features of inequality between groups of people, is the term «social stratification».

This concept explains the differences in social status as individuals and groups, emphasizes the social heterogeneity of society as a whole. Social stratification reflects the process and the result of social differentiation into social groups, which differ primarily by social status. The reasons for the division of society into strata quite diverse, and are both objective and subjective. The most important are the following reasons: income, occupation, education, property, prestige, participation in power [4, p. 166].

Meaning of "stratification" requires some explanation. In the social sciences, the term came from the geology, where with the help explain the vertical arrangement of layers of the Earth. In the social sciences the analogy between the structure of the Earth and the structure of society. The strata (social groups) are placed vertically, as the basis of income ladder stands, which occupy the top step of the rich, the middle - quite wealthy segment of the population, and the bottom - not a rich group of the population [2, p. 128].

The development of human civilization was accompanied by inequality in all its phases. In primitive society, where differences in wealth between people virtually absent, society still retained signs of inequality. Within the community, some people have a higher status because of their skills. Some members of the community were higher in relation to the other, as bravely behaved in hunting, while others were more nimble and strong, and others - were able to communicate with spirits. However, it should be stressed that was not of a pronounced character in the primitive communal system the phenomenon of stratification, as social inequality was of a minor character. With the development of human society the phenomenon of inequality have become more visible. Social inequality has divided people in terms of income, education, possession of power. Caste, class, classes - characterized by people belonging to the different levels of the social ladder. The transition from one social level to another in some societies has been allowed, in others - is prohibited. Freedom of movement characterizes the social society in terms of its closing or opening. Characterize the basic types of stratification: slave, caste, estate, class.

In ancient Egypt, China, Rome, slavery existed in Greece, Babylon, representing the legal, social, economic form of enslavement of people. History is replete with evidence of resistance on the part of numerous slaves. Unfortunately, most of the slave revolt was brutally suppressed. It should be noted that all of the system based on slavery, were unsustainable. Achieving high productivity of slave labor is achieved through cruel punishments and constant control of the slave owners. The collapse of the slaveholding system was due to the fact that economic and other incentives more effective and productive than direct coercion. The institute began to break down after the slaves in the Americas gained complete freedom.

Describing the caste system, it is important to emphasize that it is peculiar to the few countries. Through the slave system we had very many countries, of course, to varying degrees, and partly peculiar caste Africa and the whole of India. India is the classic example of the caste system, caste organization it covers the entire social system. 
From birth, every citizen of India belongs to a particular caste, part of a social group. In life, the transition from one caste to another is prohibited. To move from one caste to another person must be born again. The Hindu caste religion reinforces its position in the postulates. According to her views, each person lives more than one life, and more. Staying in a certain caste depends on how the people behaved in a previous life. In the 50s of the last century the caste system in India was banned, but manifestations of caste prejudice and inequality can be found in modern India.

Social Group, with its fixed by custom, law and possessing legal and hereditary rights and responsibilities called estate. Class status determines the location in the social hierarchy, if the class held a high position in society, it has high status. Individual manifestations of mobility also occasionally allowed. For example, to become a knight of the common man, he had to buy a special title of the ruler. This relic is still practicing in modern England. Medieval France is the most visible example of caste system; it at the time had the following class: peasants, artisans, merchants, servants, nobles, and clergy.

The class system in many respects different from the slave, class, caste. The classes, unlike other types of strata are independent of religious or legal concepts. Belonging to a particular class does not depend on the innate status, whatever it was determined - customs or laws. In comparison with the above stratification system and class system more dynamic, each class boundaries are not clear unambiguous outlines. Formal restrictions on marriages between people from different classes do not exist [1, p. 331].

Thus, we can say that there is a typical stratification, social division of society, which is characterized by hierarchy, support numerous social institutions, this phenomenon is reproducible and constantly changing. Physiological and psychological characteristics of people can be a natural cause for the emergence of social inequality. Economic, political, legal, cultural structure of the society give rise to social inequality in a fairly unchanging form.

\section{Литература}

1. Giddens E. Sociology, M.: Editorial URSS, 1999. - 704 p.

2. Kravchenko A.I. Sociology: General course: a training manual. M.: Perce; Logos, 2002. 640 p.

3. Tadevosyan E.V. Sociology: a tutorial. M.: Knowledge, 1999. - 272 p.

4. Shkaratan O.I. Sociology of inequality. Theory and reality. M.: Publishing. Home Higher School of Economics, 2012. - 526 p.

5. Shkaratan O.I., Radayev V.V. Social stratification: the manual. M.: Nauka, 1995. - 237 p. 